\title{
Effect of summer season on correlation coefficient in bird of paradise (Strelitzia reginae) progenies
}

\author{
Airadevi P. Angadi", B. S. Reddy, R. C. Jagadeesha, Balaji S. Kulkarni and S. Nishani \\ Kittur Rani Channamma College of Horticulture (KRCCH) Arabhavi, University of Horticultural Sciences, \\ Bagalkot-587102 (Karnataka), INDIA \\ *Corresponding author. E-mail: abhayaa9@gmail.com \\ Received: June 12, 2016; Revised received: October 18, 2016; Accepted: February 3, 2017
}

\begin{abstract}
The study pertaining to the effect of summer season on correlation analysis in bird of paradise (Strelitzia reginae) was carried out among forty progenies. The results of correlation analysis for twelve parameters (plant height, stem girth, leaf length, leaf width, number of leaves per plant, number of suckers $/ \mathrm{m}^{2}$, flower stalk length, flower stalk girth, spath length, no. of bracts, vase life and no. of flowers $/ \mathrm{m}^{2}$ ) at genotypic and phenotypic levels revealed that number of flowers per $\mathrm{m}^{2}$ of progenies during summer, 2011 showed positive and significant correlations with plant height $(0.357$ and 0.237$)$ and number of suckers $/ \mathrm{m}^{2}(0.880$ and 0.899$)$. Whereas, it showed positive and significant correlation with stem girth (0.203), leaf width (0.202) and flower stalk girth (0.265) at genotypic level only. While during summer 2012, number of flowers per $\mathrm{m}^{2}$ showed positive correlations with plant height $(0.265$ and $0.242)$, stem girth $(0.232$ and 0.215$)$, number of suckers $/ \mathrm{m}^{2}(0.913$ and 0.900$)$ and flower stalk length $(0.268$ and 0.249 ) at genotypic and phenotypic levels. Hence, the selection of these characters would be effective in improving yield in bird of paradise crop.
\end{abstract}

Keywords: Bird of paradise, Correlation, Flower stalk, Progenies, Stem girth

\section{INTRODUCTION}

Bird of paradise (Strelitzia reginae) belonging to the family Strelitziaceae is one such flower, which has great potential globally. This slow growing, evergreen perennial is native to the subtropical coasts of southern Africa and is widely grown in warm regions (Hensley et al., 1998). It is highly prized as cut flower due to brilliant colour and unusual appearance of the spectacular flower. Therefore, the crop is cultivated in many parts of the world in order to produce cut flowers for both domestic and international market. They are gaining popularity among the flower growers of India owing to the fact that they can be successfully grown with little care and attention and they do fairly well under partial shade also. For any crop improvement programme, selection of superior parents is an essential prerequisite; the improvement of yield is one of the main objectives of any breeding programme. But yield being a complex character is controlled by large number of characters. Hence, it becomes necessary to investigate how these characters contribute to yield, i.e. to find out how they are interlinked and its magnitude and direction of association. The idea of correlation was presented by Galton (1889) and later elaborated by Fisher (1918) and Wright (1921). A positive genetic correlation between two desirable traits makes the job of the plant breeder easy for improving both traits simultaneously. With these considerations in mind, the present study focuses on the correlation association among various characters in Bird of Paradise.

\section{MATERIALS AND METHODS}

The present investigation was carried out at Horticulture Research Station, Kanabargi Farm (Belgaum), University of Horticultural Sciences, Bagalkot (Karnataka) during 2011-2012 involving forty progenies of Bird of Paradise (Strelitzia reginae) to find to the nature and extent of correlation studies for vegetative, flowering and yield parameters. Forty plants were chosen from the Bird of paradise population. From these plants, suckers were removed and planted as plant to progeny rows, with ten plants per row with three replication and these were evaluated. Observations were recorded on forty progeny rows during summer season 2011-2012. The experiment was laid out in RCBD design with three replications. Knowledge of the relationship among yield components is essential for the formulation of breeding programme. Probably the main cause of genetic correlation is due to pleiotrophic effects of genes, i.e. some of genes which affect one trait also affect the other. If the correlation is high, then probably pleiotrophy is important and if the correlation is low then we might say that the two traits are inherited independently as they are under the control of different sets of genes. Genotypic and phenotypic correlation coefficients among twelve parameters were 
estimated as per the procedure suggested by Al. Jibouri et al. (1958). Test of significance of correlation was tested by comparing the ' $r$ ' value with obtained value. The data was subjected to statistical analysis using statistical software WINDOSTAT 9.1 developed by INDOSTAT services Ltd. Hyderabad.

\section{Results and Discussion}

Genotypic and phenotypic correlations for twelve quantitative traits among forty progenies of Bird of Paradise during summer season, 2011 are presented in Table 1 and during summer season, 2012 are presented in Table 2. For most of the characters studied the genotypic correlation was higher than the phenotypic correlations, suggesting the role of environment in diluting their associations at the level of phenotypic expressions. The results are supported by findings of Mishra et al. (1987) in dahlia and Mager et al. (2010) in chrysanthemum.

During summer 2011, plant height had significant positive correlation (at $\mathrm{p}=0.01$ ) at both genotypic and phenotypic levels with leaf length (0.445 and 0.383) and leaf width (0.309 and 0.264). Whereas, stem girth $(-0.368$ and -0.361$)$, spathe length $(-0.297$ and -0.299$)$ and vase life (-0.334 and -0.299) was negatively correlated at genotypic level only. During summer 2012, plant height had positive correlation at both the levels with leaf width $(0.460$ and 0.360$)$, number of suckers per $\mathrm{m}^{2}(0.264$ and 0.242$)$, flower stalk girth $(0.207$ and 0.199$)$ and number of flowers per $\mathrm{m}^{2}(0.265$ and 0.242 ). While, negative significant association was with stem girth and vase life. This study got support from Ranchana et al. (2013) in tuberose, who also opined that significant positive correlations for plant height was observed with yield of florets/plot (0.975), number of florets/spike (0.971) and number of leaves/ plant (0.958). Plant height had medium and significant correlation values with leaf length (0.47) and number of floral buds/plant (0.40) in day lily flower as observed by Fogaca et al. (2012). The plant height in orchid had positive significant correlation with number of leaves per cane $(0.791)$, leaf length $(0.565)$, internodal space (0.626), number of flowering canes per clump (0.662) as reported by Sunil Kumar and Swati (2013). This suggests that selection of these characters would be effective in improving total yield per plant. Positive correlations of stem girth (summer 2011), were seen with vase life (0.390 and 0.362$)$ at both levels. Positive correlation was seen for number of suckers per $\mathrm{m}^{2}(0.221)$ and number of flowers per $\mathrm{m}^{2}$ (0.203) and negative correlation was found with leaf length at genotypic level only. Stem girth (summer 2012), had positive correlation with number of suckers per $\mathrm{m}^{2}(0.237$ and 0.220$)$, vase life $(0.311$ and 0.294$)$ and number of flowers per $\mathrm{m}^{2}(0.232$ and 0.215$)$ at both levels. While, flower stalk girth $(0.183)$ was correlated at only genotypic level. Negative association was found with flower stalk length at both the levels and leaf length at only genotypic level.

Leaf length (summer 2011) had positive correlation with plant height $(0.445$ and 0.383$)$, number of leaves (0.294 and 0.210), flower stalk length (0.243 and $0.214)$ and spathe length $(0.278$ and 0.227$)$ at both levels. Negative correlations of leaf length were seen with flower stalk girth. Leaf length (summer 2012), recorded negative correlation with stem girth $(-0.188)$ and positive correlation with number of leaves per plant (0.233) at genotypic level only. At genotypic and phenotypic level positive correlation was observed for flower stalk length (0.210 and 0.186) and negative correlation was found with vase life. Similar results in gladiolus was observed by Sahana (2010) in gladiolus which showed positive correlations of leaf length with number of cormels per plant $(0.605$ and 0.549 , respectively) and plant height ( 0.861 and 0.822 , respectively) at both genotypic and phenotypic levels.

In the progenies (summer 2011), leaf width showed positive correlation with plant height $(0.324$ and 0.284$)$ at both the levels. Number of leaves per plant (0.190), number of suckers per $\mathrm{m}^{2}(0.208)$ and number of flowers per $\mathrm{m}^{2}(0.202)$ at genotypic level. Leaf width, during summer 2011 had negative correlation with flower stalk length and vase life at both the genotypic and phenotypic levels. Leaf width during summer 2012, had positive correlation with plant height $(0.460$ and 0.360 ) and negative and significant correlation with flower stalk length, flower stalk girth, spathe length and vase life at both the levels. Similar trend was reported by Nazia (2007) in heliconia, wherein the leaf width of heliconia has positive correlation with plant height (0.241 and 0.312) at both the levels.

During summer 2011, number of leaves per plant showed positive and significant correlation between plant height (0.282 and 0.239), leaf length (0.294 and 0.210 ) at both levels and leaf width (0.217) at genotypic level. Number of leaves (summer 2012) had positive correlation with plant height $(0.264$ and 0.242$)$, stem girth (0.237 and 0.220) and flower stalk length (0.526 and 0.317$)$ at both genotypic and phenotypic levels and number of flowers per $\mathrm{m}^{2}(0.252)$ at genotypic level. Significant negative correlation was observed at both genotypic and phenotypic levels with spathe length and vase life.

Number of suckers per $\mathrm{m}^{2}$ (summer, 2011) was related positively with plant height $(0.354$ and 0.235$)$ and number of flowers per $\mathrm{m}^{2}(0.880$ and 0.899$)$ at both genotypic and phenotypic levels and stem girth (0.221) and leaf width (0.208) at genotypic level only. No negative and significant association found with other characters at both the levels. Whereas, during 2012 summer, was positively related with plant height $(0.264$ and 0.242$)$, stem girth $(0.237$ and 0.220$)$, flower stalk length $(0.270$ and 0.252$)$, flower stalk girth $(0.198$ and $0.191)$ and number of flowers per $\mathrm{m}^{2}(0.913$ and 0.900$)$ 
Airadevi P. Angadi et al. / J. Appl. \& Nat. Sci. 9 (1): 364 - 369 (2017)

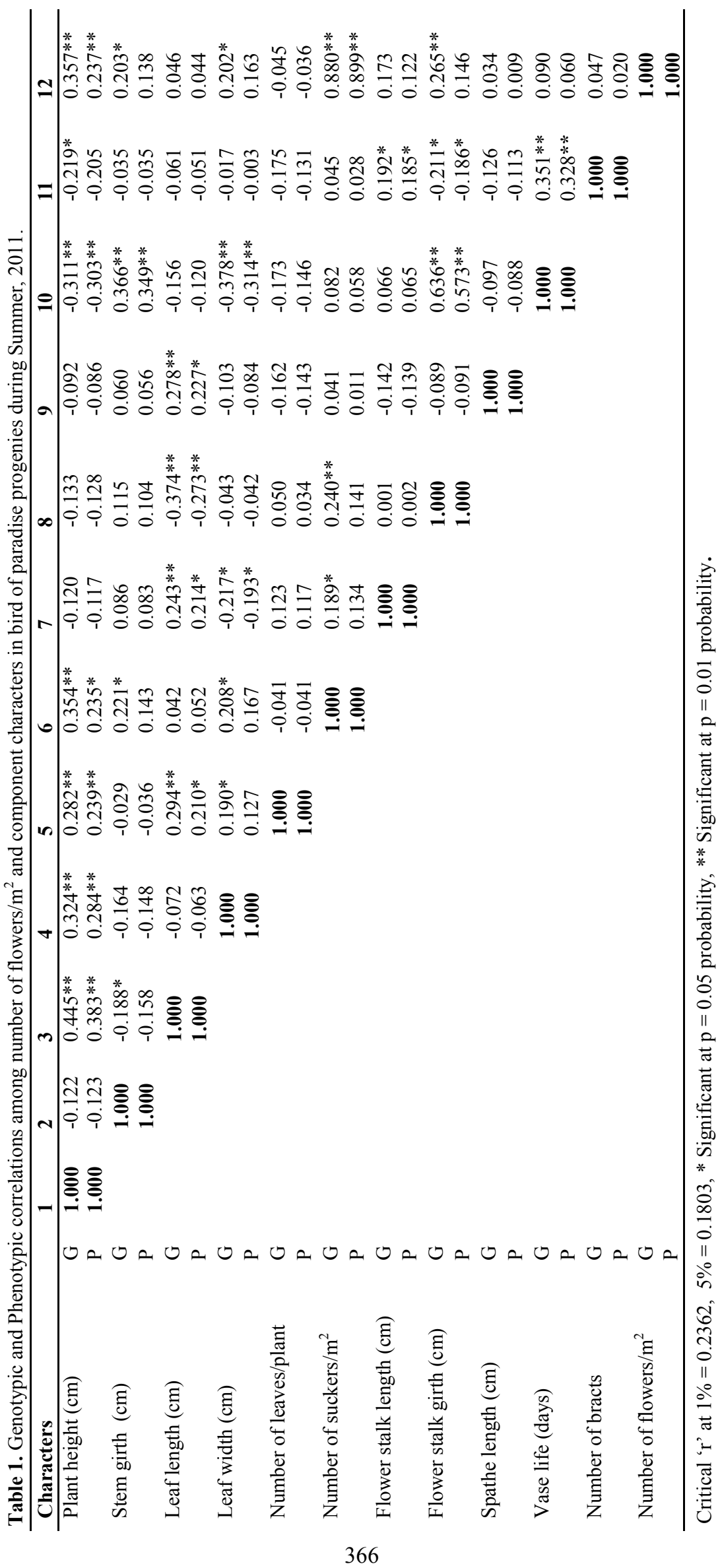


Airadevi P. Angadi et al. / J. Appl. \& Nat. Sci. 9 (1): 364 - 369 (2017)

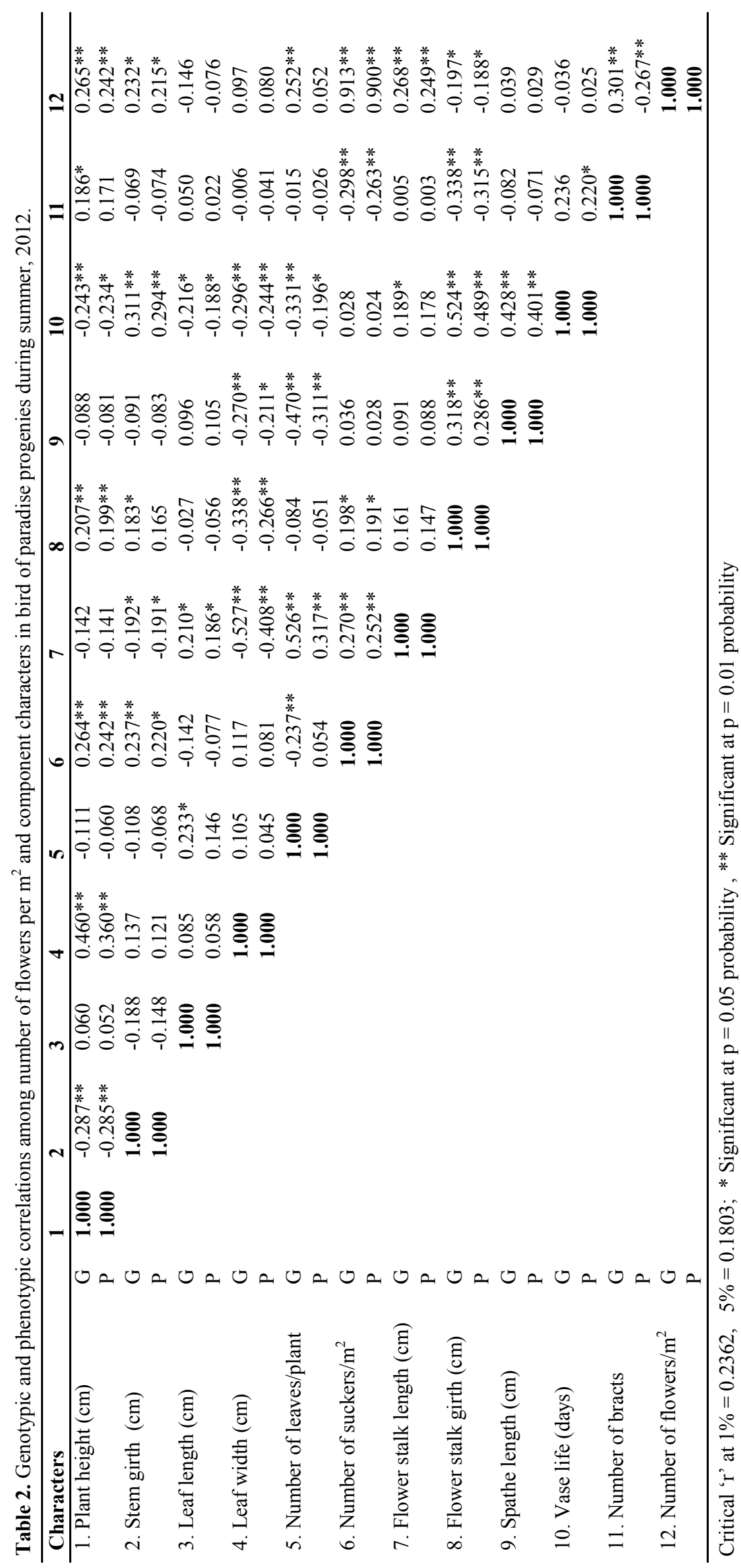


at both the level. Significant negative correlation was observed at only genotypic level with number of leaves per plant and with number of bracts at both the levels. This is in conformity with findings of Fogaca et al. (2012), where the higher correlation value was obtained between number of stems and number of floral buds/plant (0.84) in day lily flower. Bhaskaran et al. (2004) reported number of suckers/plant showed positive significant correlation with number of flowers at genotypic (0.845) as well as phenotypic (0.778) levels in chrysanthemum. Thus indicating that higher number of suckers per $\mathrm{m}^{2}$ can be used for selection of potential yielders.

With respect to qualitative parameters, among the progenies flower stalk length (summer 2011), showed positive significant correlations with leaf length $(0.243$ and 0.214$)$, number of bracts $(0.192$ and 0.185$)$ at both the levels and number of suckers per $\mathrm{m}^{2}(0.189)$ at genotypic level. Negatively significantly flower stalk length was associated with leaf width at both levels. During summer 2012, positive correlation was found with leaf length $(0.210$ and 0.186$)$, number of leaves per plant $(0.526$ and 0.317$)$ and number of suckers per $\mathrm{m}^{2}(0.270$ and 0.252$)$ and number of flowers per $\mathrm{m}^{2}$ $(0.268$ and 0.249$)$ at both levels. Whereas, vase life (0.189) at genotypic level. Negative and correlation was observed with stem girth and leaf width at both levels. Similar trend was reported by Patil et al. (2004) in carnation, that stalk length was positively significantly associated with plant height $(0.917)$, number of leaves (0.750) and leaf length (0.393).

During summer 2011, flower stalk girth had positive correlation with vase life $(0.636$ and 0.573$)$ at both levels. Negative correlation was observed with leaf length (-0.374 and -0.273$)$ and number of bracts (0.211 and -0.186 ) at both the levels. Positive and significant correlation was observed with number of suckers per $\mathrm{m}^{2}(0.240)$ at genotypic level only. During summer 2012, flower stalk girth had positive correlation with plant height (0.207 and 0.199), number of suckers per $\mathrm{m}^{2}(0.198$ and 0.191$)$, spathe length $(0.318$ and 0.286$)$, vase life $(0.524$ and 0.489$)$ at both levels. Significant negative correlation was found with leaf width, number of bracts and number of flowers per $\mathrm{m}^{2}$ at both levels. This is in accordance with findings of Nazia (2007) in heliconia, where the positive correlation of flower stalk girth was observed with vase life $(0.231)$, leaf area (0.254) and stem girth (0.189).

Among the progenies, correlation of traits with spathe length during summer 2011 exhibited positive significant (at $\mathrm{p}=0.01)$ correlation with leaf length $(0.278$ and 0.227 , respectively) at both the levels. Spathe length during summer 2012 had positive correlation with flower stalk girth (0.318 and 0.286) and vase life (0.428 and 0.401$)$ at both genotypic and phenotypic levels. Whereas, negative correlation was found with leaf width and number of leaves per plant at both geno- typic and phenotypic levels.

Vase life of progenies during summer 2011, vase life had positive correlation with flower stalk girth $(0.636$ and 0.573$)$ and number of bracts (0.351 and 0.328) at both genotypic and phenotypic levels and stem girth (0.349) at genotypic level. Negative and significant correlation was found with plant height and leaf width at both the levels. During summer 2012, vase life had positive and correlation with stem girth (0.311 and $0.294)$, flower stalk girth (0.524 and 0.489) and spathe length (0.428 and 0.401) at both genotypic and phenotypic levels and flower stalk length (0.189) at only genotypic level. Negative correlation was found with plant height, leaf length, leaf width and number of leaves per plant at both the levels. Patil et al. (2004) in carnation suggested that the vase life was positively correlated with plant height (0.614), stem girth (0.610), number of leaves $(0.488)$ and stalk length (0.685).

The correlation of number of bracts, (summer 2011) showed positive correlations with flower stalk length $(0.192$ and 0.185$)$, and vase life $(0.351$ and 0.328$)$ at both the levels of significance. Negative significant correlation was found with flower stalk girth at both the levels and plant height and number of flowers per $\mathrm{m}^{2}$ at genotypic level only. Number of bracts, during 2012 showed positive correlations with vase life $(0.236$ and 0.220$)$ at both the levels and plant height $(0.186)$ at genotypic level. Negative significant correlation found with flower stalk girth, number of suckers per $\mathrm{m}^{2}$ and number of flowers per $\mathrm{m}^{2}$ at both the levels.

Among the progenies number of flowers per $\mathrm{m}^{2}$ during summer 2011, showed positive correlations with plant height $(0.357$ and 0.237$)$ and number of suckers per $\mathrm{m}^{2}$ (0.880 and 0.899) at genotypic and phenotypic levels. Whereas, it showed positive and significant correlation with stem girth (0.203), leaf width (0.202) and flower stalk girth (0.265) at genotypic level only. During summer 2012, number of flowers per $\mathrm{m}^{2}$ showed positive correlations with plant height $(0.265$ and 0.242$)$, stem girth $(0.232$ and 0.215$)$, number of suckers per $\mathrm{m}^{2}$ (0.913 and 0.900) and flower stalk length (0.268 and 0.249 ) at genotypic and phenotypic levels. Number of flowers per $\mathrm{m}^{2}$ was negatively associated with flower stalk girth and number of bracts per inflorescence at both the levels. This indicates that increased number of suckers per $\mathrm{m}^{2}$ and stem girth will provide increased number of floral buds per plant. All these characters are closely related and together contribute to overall aesthetic quality of Bird of paradise. This suggests that selection of these characters would be effective in improving total yield per plant. This was in accordance with the reports of Sirohi and Behera (1999) in chrysanthemum, observed highly significant and positive phenotypic association of yield with number of flowers/plant (0.650), plant spread (0.597) and number of branches/plant (0.372). Positive and significant association was also observed for number of spikes/ $\mathrm{m}^{2}$ with 
yield of florets/ plot (0.565) in tuberose (Ranchana et al., 2013). This is in consonance with the findings of Sunil Kumar and Swati (2013) that the number of spikes/plant/year showed significant correlation with plant height $(0.590)$, leaf breadth $(0.591)$, internodal space (0.804) and number of flowering canes/ clump (0.958) in orchid.

\section{Conclusion}

On the basis of the inference made with respect to the high positive correlations effects of three traits viz; plant height, stem girth, numbers of suckers per $\mathrm{m}^{2}$ were investigated to be of fundamental importance in yield improvement. These characters should be given prime emphasis during selection for improvement in Bird of Paradise.

\section{REFERENCES}

Al-Jibourie, H.A., Miller, P.A. and Robinson, H.F. (1958). Genetic and environmental variance in an upland cotton cross on inter-specific origin. Agron. J., 50: 633-637

Bhaskaran, V., Janakiram, T. and Jayanthi, R. (2004). Correlation and path coefficient analysis studies in chrysanthemum. J. Ornamental Hort., 7 (3-4): 37-44

Fisher, R.A. (1918). The correlation between relatives on the supposition of Mendalian inheritance. Trans. Roy. Soc., Edinburgh, 52 : 399-433

Fogaca, L.A., Oliveira, R.A., Cuquel, F.L., Filho, J.C.B., Vendrame, W.A., Tombolato, A.F.C. (2012). Heritability and genetic correlation in daylily selection. Euphytica, 184: 301-310

Galton, F. (1889). Natural inheritance, Mc. Millon and Co.,
London. Pp: 1-257

Hensley, D., Deputy, J., Yogi, J. and Leonhardt, K. (1998). Bird of Paradise. Ornamentals and Flowers, CTAHRNov.

Mager, S.D., Warade, S.D., Nalge, N.A. and Nimbalkar, C.A. (2010). Correlation and path analysis studies in gerbera (Gerbera jamesonii). Int. J. Plant Sci., 5 (2): 553-555

Mishra, R.L, Verma, T.S., Thakur, P.C. and Singh, H.B. (1987). Variability and correlation studies in dahlia. Indian J. Hort., 44 (3-4): 269-273

Nazia Sherif. (2007). Genetic variability studies in heliconia genotypes (Heliconia spp.). M.Sc. (Hort.) Thesis, Univ. Agric. Sci., Dharwad.

Patil, R.T., Reddy, B.S., Praveen, J. and Kulkarni, B.S. (2004). Correlation studies in carnation (Dianthus caryophyllus L.). J. Ornamental Hort., 7 (3-4): 7-10

Ranchana P, Kannan M, Jawaharlal, M. (2013). Genetic and correlation studies in double genotypes of tuberose (Polianthes tuberosa) for assessing the genetic variability. Adv. Crop Sci Tech., 1: 1-5

Sahana, K. (2010). Studies on genetic variability in gladiolus (Gladiolus grandiflorum L.). M.Sc. (Hort.) Thesis, Univ. Agric. Sci., Dharwad.

Sirohi, P.S. and Behera, T.K. (1999) Correlation and path analysis studies in chrysanthemum. J. Ornamental Hort., New Series, 2 (2) : 80-83

Sunil Kumar and Swati, S. (2013). Studies on performance, genetic variability, heritability and correlation of Dendrobium orchids under agro-climatic conditions of Pasighat, Arunachal Pradesh. Intl. J. Agric. Env. Biotech., 6(1): 101-108

Wright, S. (1921). Correlation and causation. J. Agric. Res., 20: $557-585$ 